\title{
Manufacturing strategy implementation and performance benchmarking in Indian packaging product manufacturing companies
}

\author{
Pradip P. Patil
}

Mechanical Engineering Department, SIES Graduate School of Technology, Navi Mumbai, 400706, India Email: pradipp@sies.edu.in *Corresponding author

\section{B.E. Narkhede}

Department of Production and Industrial Engineering, VJTI, Mumbai, 400019, India

Email: benarkhede@vjti.org.in

\section{Milind M. Akarte}

National Institute of Industrial Engineering (NITIE), Vihar Lake, Mumbai, 400087, India

Email:milindakarte@yahoo.com

\begin{abstract}
The purpose of the paper is to assess the competitiveness of the manufacturing firm. The approach adopted for assessing the competitiveness is through manufacturing strategy implementation and performance benchmarking which will guide manufacturers for improving the current manufacturing decisions. The proposed integrated framework not only helps in quantifying and comparing the current manufacturing performance but also facilitate to pin point misaligned manufacturing decisions that needs to be focused for superior competitiveness. The intent of this paper is also to provide recommendations for plants committed to performance benchmarking. For analysing the competitiveness, plants are classified in four groups based on the increasing level of manufacturing strategy implementation using cluster analysis. A case of a manufacturing plant has been used to demonstrate its level of competitiveness and the areas of improvements based on benchmark values. Performance benchmarking is carried out by assessing difference in performance of a plant.
\end{abstract}

Keywords: competitiveness; manufacturing strategy implementation; performance benchmarking; manufacturing decisions/levers; manufacturing outputs; India.

Reference to this paper should be made as follows: Patil, P.P., Narkhede, B.E. and Akarte, M.M. (2016) 'Manufacturing strategy implementation and performance benchmarking in Indian packaging product manufacturing companies', Int. J. Competitiveness, Vol. 1, No. 1, pp.33-52. 
Biographical notes: Pradip P. Patil is working as an Assistant Professor in SIES Graduate School of Technology in Navi Mumbai, India. He received his $\mathrm{PhD}$ in Production Engineering from V.J.T.I. affiliated from the Mumbai University. He has published papers in various international journals and scientific and technical committee and editorial review board member of World Academy of Science, Engineering and Technology. His research areas are strategic manufacturing, and manufacturing system development.

B.E. Narkhede received his $\mathrm{PhD}$ from the University of Mumbai in India Currently, he is working as an Associate Professor in Production and Industrial Engineering and guiding six PhD students at the VJTI in Mumbai, India. He is serving as the Editor-in-Chief of Industrial Engineering Journal from January 2009 and also a reviewer for International Journal of Industrial Engineering in Barcelona, Spain. He is recipient of the prestigious Dr. S.R. Gollapudi Award from Indian Institution of Industrial Engineering in recognition of his substantial contribution in the field of industrial engineering.

Milind M. Akarte is an Associate Professor at the National Institute of Industrial Engineering (NITIE) in Mumbai, India. He earned his MTech in Industrial Engineering and Operations Research and $\mathrm{PhD}$ degree from the Indian Institute of Technology in Bombay. He has more than 20 publications to his credit in various international journals, national and international conference proceedings. His research areas are multi-criteria decision making, collaborative product design, product lifecycle management, strategic manufacturing and strategic procurement. He is also a reviewer for the national and international journals.

\section{Introduction}

The research on manufacturing strategy implementation has received much attention in the past, showing the improvement in the manufacturing and business performance (Skinner, 1969; Skinner, 1974; Hayes and Wheelwright, 1984; Hill, 1989; Dangayach and Deshmukh, 2001; Rho, et al., 2001; Chang et al., 2003; Thun,2008; Miltenburg, 2008; Han et al., 2012). For example, Chung and Swink (2009) has assessed the impact of advanced manufacturing technology on manufacturing outputs (quality, delivery, flexibility, cost) and reported that the implementation of advanced manufacturing technology results in improved manufacturing performance (Rosenzweig and Roth, 2004). Dangayach and Deshmukh (2008) assessed the prevalence of improvement activities and termed it as advanced management system in multi-sector analysis. They found machinery sector is improving on adoption of advanced manufacturing system as well as competitive capabilities. Miltenburg (1995) has pointed out the systematic improvement of manufacturing outputs/capabilities by improving decisions in manufacturing subsystem or levers for specific production system. This research adopts the terminology coined by Miltenburg (2008) for decisions in manufacturing system as manufacturing levers and manufacturing performance as manufacturing outputs.

In an empirical study, Thun (2008) showed that general manufacturing strategy implementation promote development of resource based manufacturing strategy (improvement in structure, infrastructure and capabilities/outputs). The resource based view strategy comprises specific decisions or activities (internal resources to plant, such 
as human resource, process technology, facilities) in the manufacturing system. It gives an advantage which will be difficult for competitor to copy (Prahalad and Hamel, 1990). Coates and McDermott (2002) pointed out that the competitiveness of the manufacturing plants should be based on their resources and can be viewed as better point of differentiation. On the other hand, Porter (1985) pointed out that disparity in the performance stems from an inability to translate a competitive strategy into specific implementation plan. Several authors have pointed out that manufacturing competence can be assessed by finding the consistency between competitive priorities and manufacturing outputs (Cleveland et al., 1989; Vickery et al., 1993; Kim and Arnold, 1996). Competitive priorities denote strategic intent on developing certain manufacturing capabilities that may improve competitive position of the plant in marketplace (Hill, 1989). Larger this consistency, more manufacturing can contribute to business performance of the plant (Demeter, 2003).

There are two purposes of this paper. First one is to evaluate the general manufacturing strategy implementation in IPPMC by extending the work of Thun (2008). For this, an integrated framework is proposed to find out whether general manufacturing strategy implementation support better decision making in manufacturing levers (or subsystems like HR, PPC, etc) and whether it also improves the manufacturing and business performance.

Second purpose of this paper is to assess competitiveness of the manufacturing plants reaching towards competitive priorities in the industry. To address this difference in performance of the plants, performance benchmarking is carried out using the methodology adopted (Demeter, 2003) for assessing the consistency between importance/competitive priorities and manufacturing outputs.

This research addresses three questions as follows:

1 whether plants decision making in manufacturing function are consistent with emphasis on general implementation of manufacturing strategy

2 whether plants manufacturing performance and business performance are consistent with decision making in manufacturing decisions

3 whether performance benchmarking leads to better understanding of inconsistencies in the competitive priorities and performance of the plant.

The article proceeds as follows. The following section provides a summary of the relevant literature in the area of manufacturing decisions, manufacturing improvement programs, manufacturing strategy and their relation with manufacturing performance and business performance. The next section describes the research design which includes sample data collection, introduction to IPPMC and measures for analysis. This is followed by the discussion on data analysis and results. It includes a methodology to classify manufacturing firms into four groups, result analysis for manufacturing strategy implementation across group, and a case example for a company. In the last section conclusion, managerial implications, limitations and future scope is highlighted.

\section{Literature review}

According to Hayes and Wheelwright (1984) manufacturing strategy is a pattern of decisions, both structural and infrastructural, which determine the capability of a 
manufacturing system and specify how it will operate to meet a set of manufacturing objectives that are consistent with overall business objectives while taking into account market needs, competitor performance, internal strength and weaknesses. Structural decisions include process technology, and facilities; while infrastructural decisions include human resource, production planning and control, organisation structure and control, and sourcing. Hayes and Wheelwright (1984) also pointed out four stages of progression toward attainment of a truly competitive manufacturing strategy. This progression (internally neutral, externally neutral, internally supportive and externally supportive) leads to developing better manufacturing capability and superior manufacturing performance. The competitive advantage can be achieved by providing manufacturing capabilities or outputs (quality, cost, delivery, flexibility, and time) to the customer (Schroeder and Flynn, 2001). The firm can exploit the capabilities to enhance the performance and strategically position the firm in the market (Rosenzweig et al., 2003).

Competitiveness refers to the ability of a business organisation to survive in a competitive marketplace by offering products or services that attract and satisfy customers (Fujimoto, 2004). Moreover, Singh et al. (2007) have compiled the definitions of competitiveness from literature and empirically found that strategies for investment, cost reduction, quality improvement, and competency development significantly predict an organisation's competitiveness. After assessing competitiveness of the plants, benchmarking can be carried out. The benchmarking is a process of identifying best practices for excellence in product, services or processes (Bhutta and Huq, 1999) and 'the search of implementation of best practices' [Camp, (1995), p.15]. Hong et al. (2012) have discussed five research dimensions: strategy-based benchmarking; operationaleffectiveness benchmarking; technical-efficiency based benchmarking and micro-macro integrative benchmarking. They pointed out the need for going beyond operational level into strategic level for competitive advantage. However, the purpose of performance benchmarking is to establish and validate objectives for the vital few performance measures that guide the organisation [Camp, (1995), p.16]. On the other hand, performance benchmarking is carried out for one type industry also (Camp, 1995). The performance benchmarking carried out in this study is for only one industry, i.e., IPPMC.

In assessing performance of US manufacturing units, Miller and Roth (1994) classified manufacturing units into three clusters; caretakers, marketers, innovators. In classifying, they found differences among group in terms of action programs to improve the effectiveness of operations over following two years. The action programs include; labour/management relationships, zero defects, manufacturing lead time reduction, $\mathrm{CAD}$, new process/product, closing plants, new product introductions, reducing workforce size. De Mayer (1998) provided trend in implementation of action programs over 1986-96. Some of the significant action programs, which leads to higher competitive priorities for European manufacturers includes closing and relocating plants, functional team work, value analysis, computer aided design, reconditioning physical plants, developing new process for existing products, flexible manufacturing systems, robots, production and inventory control. Indian manufacturers are also adopting technologies for developing capabilities which enhance the product and process improvements (Iyer et al., 2011). Empirical study of Indian packaging product manufacturer, reported a significant impact of process technology on delivery and innovativeness (Patil et al., 2012b).

The issue of manufacturing strategy is studied in literature as process based (Choudhari et al., 2012) and non-process based decision making (Dangayach and 
Deshmukh, 2001; Swink et al., 2007). The process specific decision is directly related with production system for ex. Set-up time, whereas non-process specific decisions affect the production system for ex, planning process as centralised or decentralised. The manufacturing strategy implementation is a process of deploying decisions related to the objectives and competence for improvements in manufacturing output. For this, it is necessary to be proactive in decision taking related to manufacturing domain. Porter (1980) highlighted the need for integration of manufacturing function with other functions in a value chain framework. The communication of strategic plans is pertinent in understanding long range plan by the employees.

It is reported that operating decision are important while making trade-off among competitive priorities between cost, flexibility, delivery, quality (Boyer and Lewis, 2002; Rosenzweig and Easton, 2010).

The above discussion provides evidence of empirical research of manufacturing strategy implementation on manufacturing and business performance. Also implications of manufacturing practices or decisions are related to manufacturing and business performance. The above discussion from literature review provides the clear evidence indicating the importance of MS (pattern of decisions) for improving the manufacturing performance and business performance and hence the competitiveness of a firm. Therefore, we can conclude that better understanding of manufacturing decisions and its relationship with manufacturing outputs and business performance is essential to improve the competitiveness of a firm. Hence, this research work is focused on establishing a relationship between input side (pattern of decisions) and output side (manufacturing and business performance) of a manufacturing function. That is, assessing the manufacturing strategy implementation (pattern of decisions) and its impact on manufacturing outputs and business performance in IPPMC, differentiating this work from rest of the literature available in the manufacturing strategy domain to the best of our knowledge. In additional, a performance benchmarking for a sample manufacturing firm has been presented from less manufacturing strategy implementer group to demonstrate

\section{Research design}

This research employs the constructs borrowed from literature (Thun, 2008; Dangayach and Deshmukh, 2004), for assessing existence of manufacturing strategy among Indian packaging product manufacturing companies (IPPMC). In order to assess emphasis on key decision areas, authors operationalised the decisions/subsystem using the literature (Avella et al., 2001; Miltenburg, 2008; Dangayach and Deshmukh, 2006).

This research explores the characteristics of manufacturing plants based on the analogy created to Hayes and Wheelwright's (1984) work on stages of manufacturing and methodology to group the plants based on manufacturing strategy implementation (Patil et al., 2012a). The plants are classified into four groups (less-implementer, strategicallyoriented, high-implementer and strategically-focused). Plants were analysed for manufacturing strategy implementation, related decisions in manufacturing levers and the manufacturing and business performance. The framework has been developed to study the implications of manufacturing strategy implementation on manufacturing levers and manufacturing output and business performance. Figure 1 shows conceptual model for this research. 
Figure 1 Linking MSI to manufacturing levers, manufacturing outputs and business performance

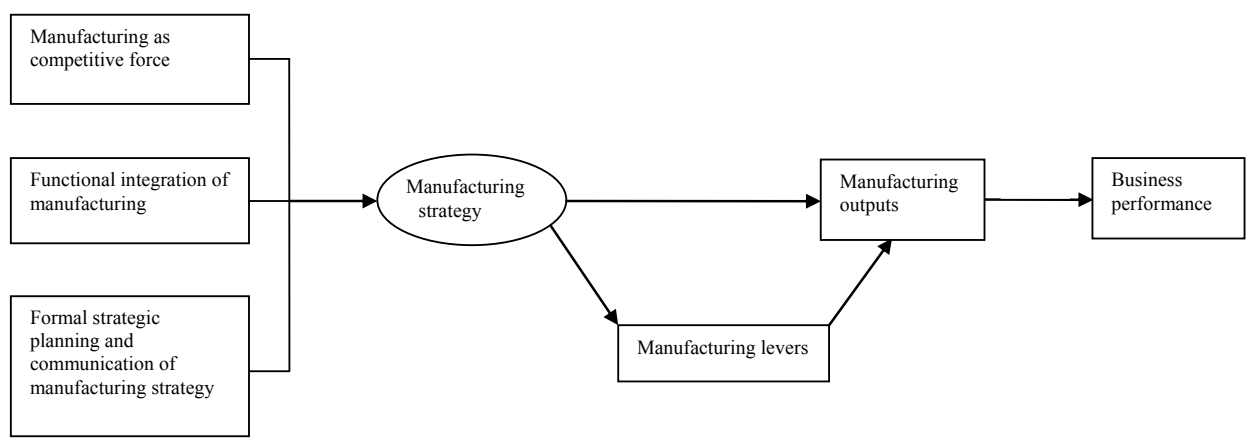

\section{Research database and sample}

This is cross-sectional and prospective study and questionnaire-based mail survey methodology and face-to-face interview, using sampling technique. In order to assess the research problem, Indian packaging product manufacturing companies (IPPMC) are selected and database of 510 packaging production companies has been created based on packaging product manufacturing industries from all over the country (DPPBI, 2005; DPMMI, 2009; IYD, 2009). Selection criteria were based on number of employees and an annual sale turnover during year 2010. Table 1 shows region wise data of companies and response rate.

Table 1 Region wise data

\begin{tabular}{lcc}
\hline Region & No. of questionnaire sent (\%) & No. of companies responded (\%) \\
\hline East & $50(9.8)$ & $8(7.1)$ \\
West & $180(35.29)$ & $105(48.2)$ \\
North & $120(23.25)$ & $26(17.85)$ \\
South & $160(31.37)$ & $56(26.78)$ \\
Total & $510(100)$ & $195(100)$ \\
\hline
\end{tabular}

\section{Introduction to IPPMC}

Outputs (packaging machinery) produced by IPPMC is used in wide variety of manufacturing industries including the consumer product manufacturing companies. The Indian packaging industry is growing at $14-15 \%$ annually (IPMMI, 2009) and it is a $\$ 14$ billion in market size. The annual per capita consumption of flexible packaging in India is $\$ 1$, while that of North America is $\$ 45$, and West Europe is $\$ 25$ (Ravi, 2010). India stands at twelfth national market with USA, Japan and China leading the consumption of packaging materials (WPO, 2008). Geetha (2010), while exploring the facility and features of 'Uflex Ltd.', one of the largest company offering flexible packaging solutions, found that this firm is employing latest machines for ensuring timely delivery and maintaining superior quality product. Geetha also pointed out that firm is developing 
capability in terms of in-house development of products, product innovations and maintaining long-term contract with suppliers.

Levis (2011) has found little difference in technology between Indian and global packaging product manufacturers, but, found great difference in utilising the machinery and retaining the skilled manpower. The packaging industry is moving towards automating the plant employing robots; sensor technology in manufacturing system (Monga, 2010). Monga has also focused on need for flexibility, reliability of production system. He also pointed out that technology plays a vital role in fulfilling the market demand.

The product innovation in packaging industry improves the business performance (Sheth, 2010). The reluctance to invest in design activity has been major issue in development of capability and learning. For packaging industry, designing a new product is critical in identifying opportunities in manufacturing process development. The FMCG industry is relying heavily on packaging aspect of product design. Gagan (2010) feels that India would be the major centre for global packaging components. The industry is under pressure to innovate and develop products with different materials, with varying customer needs (Joshi, 2010). The growth of global packaging industry is placing heavy demand in terms of manufacturing outputs (WPO, 2008).

\section{Measures}

Based on the literature a questionnaire on manufacturing strategy implementation is designed. It mainly include three factors, namely manufacturing as competitive force (MCF), functional integration of manufacturing (FIM) and formal strategic planning and communication of manufacturing strategy (SPC). The questions on manufacturing strategy implementation are developed to find prevalence of the factors and measured on five point Likert scale (1-not at all, 5-large extent). Questions related to manufacturing levers are adopted from (Avella et al., 2001; Miltenburg, 2008; Dangayach and Deshmukh, 2006). The questions on manufacturing levers are developed to find emphasis (or investment) in activities in the last three years and measured on five point Likert scale (1-not at all, 5-large extent). However scale for manufacturing outputs were adopted from Miltenburg (2008) and Swink et al. (2007) and changes in manufacturing output in last three years in the plant primary product line are measured on five point Likert scale (1-not at all, 5-large extent). Selected measures for business performance include sales growth and customer satisfaction (Rosenzweig et al., 2003). It is a closed-ended type of questions that allows respondents to indicate how closely their feelings match the question or statement on a rating scale. The constructs and the measures are adopted from the representative literature as shown in Table 2.

To assess content validity a pilot study is carried out and few questionnaires were administered to academic and industry experts. The content validity assesses the degree of correspondence between the items selected to develop measurement scale. Based on their feedback and the comments, final version of the questionnaire was sent to 510 companies. The unavailability of qualified individuals and lack of interest are some of the reasons for non-response from participants in the study. About 22 responses were discarded for incomplete information resulting in usable sample size of 195 with response rate $38.24 \%$. Table 3 shows profile of respondent IPPMC. 
Table 2 Constructs, measurement items, and representative literature establishing content validity

\begin{tabular}{|c|c|c|}
\hline Constructs & Measurement items & Representative literature \\
\hline $\begin{array}{l}\text { Manufacturing } \\
\text { strategy } \\
\text { implementation }\end{array}$ & $\begin{array}{l}\text { Manufacturing as competitive force, } \\
\text { functional integration of } \\
\text { manufacturing,strategic planning } \\
\text { and communication }\end{array}$ & $\begin{array}{l}\text { Thun (2008) and Dangayach and } \\
\text { Deshmukh (2004) }\end{array}$ \\
\hline $\begin{array}{l}\text { Manufacturing } \\
\text { levers }\end{array}$ & $\begin{array}{l}\text { Human resources, organisation } \\
\text { structure and control, production } \\
\text { planning and control, sourcing, } \\
\text { process technology, facilities. }\end{array}$ & $\begin{array}{l}\text { Miltenburg (2008), Swink et al. } \\
\text { (2005), Bayazit and Karpak } \\
\text { (2007), Swink et al. (2007) and } \\
\text { Karim et al. (2008) }\end{array}$ \\
\hline $\begin{array}{l}\text { Manufacturing } \\
\text { outputs }\end{array}$ & $\begin{array}{l}\text { Cost, quality, delivery, performance, } \\
\text { flexibility, innovativeness }\end{array}$ & $\begin{array}{l}\text { Miltenburg (2008), Demeter } \\
\text { (2003), Flynn et al. (1999) and } \\
\text { Narasimhan and Jayaram (1998) }\end{array}$ \\
\hline $\begin{array}{l}\text { Business } \\
\text { performance }\end{array}$ & Sales growth, customer satisfaction & $\begin{array}{l}\text { Rosenzweig et al. (2003) and } \\
\text { Swink et al.(2007) }\end{array}$ \\
\hline
\end{tabular}

Table 3 Profile of the respondent IPPMC

\begin{tabular}{|c|c|c|c|}
\hline \multicolumn{2}{|c|}{ Parameter } & Number of companies & Percentage \\
\hline \multicolumn{4}{|c|}{ Number of employees } \\
\hline 1 & $<100$ & 58 & 29.7 \\
\hline 2 & $100-249$ & 126 & 64.7 \\
\hline 3 & $250-499$ & 8 & 4.1 \\
\hline 4 & $500-999$ & 2 & 1 \\
\hline 5 & $>1000$ & 1 & 0.5 \\
\hline \multicolumn{2}{|c|}{ Total } & 195 & 100 \\
\hline \multicolumn{2}{|c|}{ Sales turnover (Rupees million) $1 .<50$} & 65 & 33.3 \\
\hline 2 & $50-<200$ & 61 & 31.2 \\
\hline 3 & $200-<400$ & 45 & 23.1 \\
\hline 4 & $400-<800$ & 36 & 18.4 \\
\hline 5 & $>800$ & 12 & 6 \\
\hline \multicolumn{2}{|c|}{ Total } & 195 & 100 \\
\hline \multicolumn{4}{|c|}{ Respondent } \\
\hline 1 & $\begin{array}{l}\mathrm{CEO} / \mathrm{GM} / \text { president/vice president/executive } \\
\text { director (with } 21 \text { years and above experience) }\end{array}$ & 94 & 48.2 \\
\hline 2 & $\begin{array}{l}\text { Divisional manager/production manager/head- } \\
\text { operations/works manager/director-technical } \\
\text { (with 10-20 years experience) }\end{array}$ & 73 & 37.4 \\
\hline 3 & $\begin{array}{l}\text { Assistant manager/production engineer/quality } \\
\text { engineer (with 5-9 years experience) }\end{array}$ & 28 & 14.4 \\
\hline \multicolumn{2}{|c|}{ Total } & 195 & 100 \\
\hline
\end{tabular}


Table 4 Confirmatory factor analysis

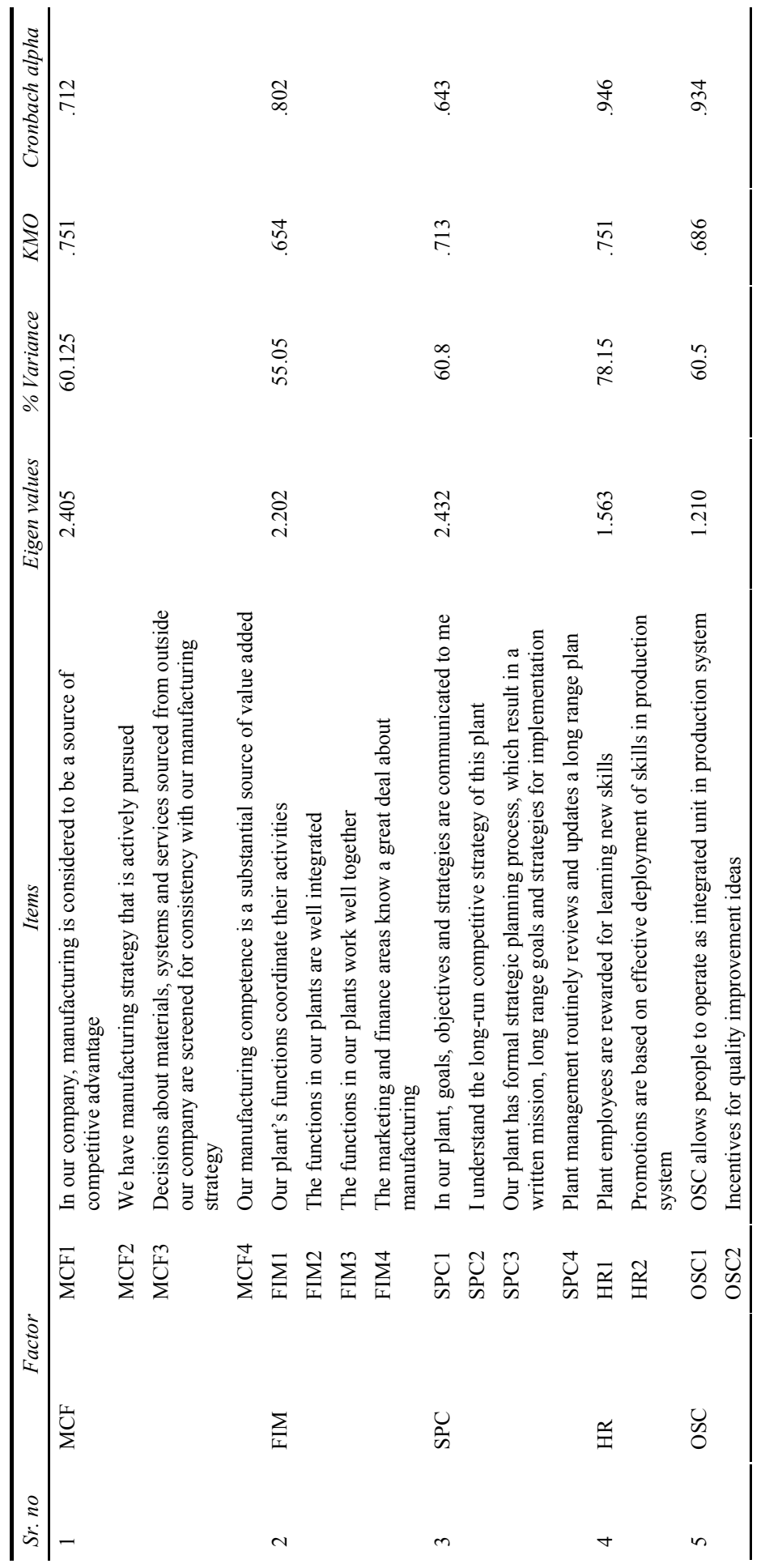


Table 4 Confirmatory factor analysis (continued)

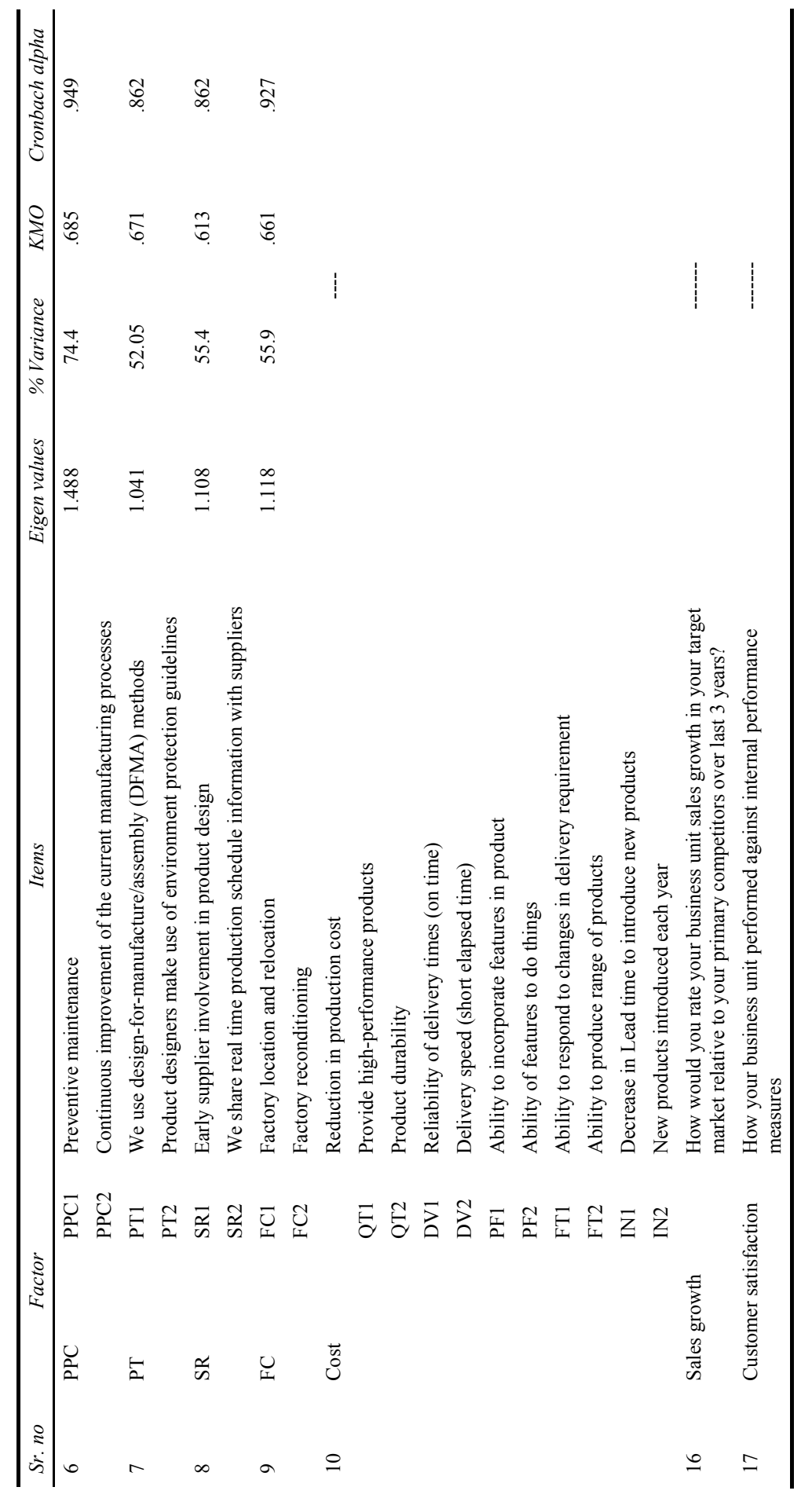


The validity and reliability were assessed through determination of content validity, Cronbach alpha coefficients, and factor analysis. The Cronbach's alpha is found to test the reliability of measure which varies from 0 to 1 . The scale developed for measuring various constructs was adopted from previous research (Avella et al., 2001; Miltenburg, 2008). All the items used were from previous studies and did not represent new scales and provides content validity of the scale (Hair et al., 2010).

After collecting the data, confirmatory factor analysis for each construct is carried out as shown in Table 4.The Eigen values of each construct exceeds minimum threshold of 1.0 (Thun, 2008), KMO (Kiser Mayer Oklin) factor for sampling adequacy is found more than 0.6 which is adequate for exploratory work (Hutcheson and Sofroniou, 1999) and the percent variance explained by each factor is greater than $50 \%$. Cronbach alpha coefficients are calculated for checking internal consistency and reliability of scales and found more than 0.7 except for SPC (0.643), which is adequate for exploratory work (Nunally, 1978).

\section{Observations and results}

This section provides the results of data analysis to draw a meaningful inference. First, grouping of data was carried out to assess the manufacturing strategy implementation within the firms participated in this research. In second stage, data analysis was carried out to understand the manufacturing decisions and its relationship with manufacturing outputs and business performance across the groups. Finally, a case example has been discussed to quantify and compare the current manufacturing performance of a firm and to highlight misaligned manufacturing decisions that need to be focused for superior competitiveness. These are briefly discussed next.

\subsection{Methodology to identify manufacturing groups}

The aim of grouping 195 firms into four groups is to classify them based on general implementation of manufacturing strategy. These groups are named as less-implementer, strategically-oriented, high-implementer and strategically-focused, which are in line with the four stages (internally neutral, externally neutral, internally supportive and externally supportive) of progression of manufacturing as given by Hayes and Wheelwright (1984). The statistical process adopted in forming four groups is as follows.

Four groups are formed using k-mean cluster method and cluster centres are found employing Ward method with squared Euclidian distance. The cluster centres show four distinct centres and based on cluster membership information each plant is assigned to a cluster with less distance between the case and cluster centre. ANOVA of variables for cluster is carried out to assess variance and found that MCF and FIM explain more variance which is significant beyond 0.05 level. Discriminant analysis of the clusters is carried to find difference in mean values of four groups. Wilk's lambda is found to assess ratio of within-group sum of square to total sum of square. The smaller values near zero shows indicate much difference in mean values which is significant beyond 0.05 level. The analysis of canonical discriminant function shows that one discriminant function with Eigen value of 3.653 explaining $84.8 \%$ of variance. 
The test of difference in the mean values of discriminant functions is assessed using Wilk's lamda. The value of 0.106 shows difference in the functions with chi-square value of 256.11 which is significant beyond 0.05 level. The standardised canonical discriminant function coefficients show the relative contribution of the variable to the overall discrimination and found that coefficients are more for functional integration of manufacturing variables. The structure matrix shows within-group correlation of each variable with the canonical function. The correlation of MCF and FIM factors are important to differentiate between less to higher manufacturing strategy implementer group. The classification result shows that $97.5 \%$ of the original grouped cases and $89.7 \%$ of the cross validated grouped cases are correctly classified. Table 5 shows differences in mean values for manufacturing strategy; manufacturing levers; manufacturing and business performance ( $\mathrm{t}$-values are significant beyond 0.05 level).

Table 5 Difference in manufacturing strategy implementation, manufacturing levers, manufacturing and business performance across groups

\begin{tabular}{|c|c|c|c|c|c|}
\hline Variable & $\begin{array}{c}\text { A case in } \\
\text { less-implementer } \\
\text { group }\end{array}$ & $\begin{array}{c}\text { Less- } \\
\text { implementer* }\end{array}$ & $\begin{array}{l}\text { Strategically- } \\
\text { oriented } *\end{array}$ & $\begin{array}{c}\text { High } \\
\text { implementer* }\end{array}$ & $\begin{array}{l}\text { Strategically- } \\
\quad \text { focused }^{*}\end{array}$ \\
\hline MCF1 & 2 & 1.714 & 2.679 & 3.459 & 3.624 \\
\hline MCF2 & 3 & 1.286 & 1.893 & 2.388 & 3.865 \\
\hline MCF3 & 2 & 1.714 & 2.179 & 3.376 & 3.964 \\
\hline MCF4 & 2 & 2.214 & 1.643 & 3.906 & 3.985 \\
\hline FIM1 & 2 & 1.000 & 3.893 & 3.976 & 3.956 \\
\hline FIM2 & 2 & 1.214 & 1.464 & 3.847 & 3.809 \\
\hline FIM3 & 1 & 1.786 & 2.214 & 2.729 & 3.103 \\
\hline FIM4 & 1 & 2.357 & 2.357 & 2.600 & 4.123 \\
\hline SPC1 & 1 & 1.786 & 2.250 & 2.612 & 4.915 \\
\hline SPC2 & 2 & 2.143 & 2.286 & 2.753 & 3.412 \\
\hline SPC3 & 3 & 1.846 & 2.393 & 2.659 & 3.456 \\
\hline SPC4 & 2 & 1.714 & 2.464 & 2.647 & 3.865 \\
\hline MSI_avg. & 1.92 & 1.73 & 2.31 & 3.08 & 3.84 \\
\hline HR1 & 1 & 1.07 & 2.78 & 2.93 & 3.95 \\
\hline HR2 & 2 & 1.34 & 2.89 & 3.24 & 3.98 \\
\hline OSC1 & 2 & 1.43 & 2.97 & 2.3 & 3.75 \\
\hline OSC2 & 2 & 1.56 & 2.76 & 3.23 & 4.02 \\
\hline PPC1 & 2 & 2.21 & 2.99 & 3.64 & 3.91 \\
\hline PPC2 & 3 & 2.34 & 3.04 & 3.23 & 4.11 \\
\hline PT1 & 2 & 1.78 & 2.96 & 3.89 & 4.34 \\
\hline PT2 & 3 & 2.21 & 3.23 & 3.78 & 4.2 \\
\hline SR1 & 1 & 1.21 & 1.81 & 2.46 & 3.85 \\
\hline SR2 & 2 & 2.21 & 2.45 & 3.21 & 3.23 \\
\hline $\mathrm{FC} 1$ & 2 & 1.79 & 2.1 & 3.21 & 3.73 \\
\hline
\end{tabular}


Table 5 Difference in manufacturing strategy implementation, manufacturing levers, manufacturing and business performance across groups (continued)

\begin{tabular}{lccccc}
\hline Variable & $\begin{array}{c}\text { A case in } \\
\text { less-implementer } \\
\text { group }\end{array}$ & $\begin{array}{c}\text { Less- } \\
\text { implementer }\end{array}$ & $\begin{array}{c}\text { Strategically- } \\
\text { oriented }\end{array}$ & $\begin{array}{c}\text { High } \\
\text { implementer* }\end{array}$ & $\begin{array}{c}\text { Strategically- } \\
\text { focused }^{*}\end{array}$ \\
\hline FC2 & 1 & 1.92 & 2.45 & 3.32 & 4.34 \\
Cost & 2 & 2.14 & 2.41 & 2.29 & 3.75 \\
QT1 & 3 & 1.93 & 1.82 & 2.39 & 3.66 \\
QT2 & 2 & 1.78 & 2.23 & 2.67 & 3.34 \\
DV1 & 2 & 1.71 & 1.85 & 2.46 & 3.65 \\
DV2 & 2 & 1.56 & 2.21 & 2.67 & 3.23 \\
FT1 & 3 & 1.57 & 1.94 & 2.21 & 3.65 \\
FT2 & 2 & 1.34 & 1.98 & 3.02 & 3.47 \\
PF1 & 2 & 2.14 & 2.4 & 3.39 & 3.87 \\
PF2 & 3 & 2.52 & 2.78 & 3.43 & 3.67 \\
IN1 & 3 & 1.29 & 1.76 & 2.71 & 3.53 \\
IN2 & 2 & 1.34 & 2.01 & 2.68 & 3.67 \\
Sales growth & 3 & 2.36 & 2.85 & 3.36 & 3.98 \\
Customer & 2 & 1.79 & 1.91 & 2.25 & 3.61 \\
satisfaction & & 68 & 85 & 28 & 14 \\
No. of plants & 1 & & & & \\
\hline
\end{tabular}

\subsection{Manufacturing strategy implementation across groups}

The status of manufacturing plants in IPPMC shows that there is a wide difference in the manufacturing strategy implementation (Table 5). If we compare the less implementer with strategically focused group for the mean values of MFC, FIM, SPC, manufacturing levers, manufacturing performance and business performance then the difference is $55 \%$, $52 \%, 58 \%, 56 \%, 34 \%$ and $45 \%$ respectively. There is much difference in general implementation of manufacturing strategy and decision making in manufacturing levers in two groups, and great difference is observed in manufacturing and business performance. It is also observed that there is a steady increase in the mean values of all measures (Table 5) as we move from less implementer to strategically focused group with an exception for FIM1 and FIM2 for high implementer and strategically focused. This confirms the wide difference for manufacturing strategy implementation in the plants. Strategically focused group is found better at much extent in the communicating strategic planning (goals, objectives and strategies), manufacturing competence as source of value added, knowledge of manufacturing function to marketing and finance compared to other three groups. On the other hand, not much difference is found in functional working well together among all the groups.

The emphasis on manufacturing as substantial source of value added (MCF4) is found consistent with the improvement in decision making in continuous improvement of current production processes (PPC2) and use of DFMA methods (PT1) for all the groups. Though the functions in the plant are well integrated structurally (FIM2), but there is less improvement in allowing people to operate as integrated unit in production system 
(OSC1) across all the groups (Table 5). In human resource lever, though promotions are based on effective deployment of skills in production system (HR2), reward for learning new skills is not given due importance in the groups (HR1) and reflected in lower level of innovation (IN1). In organisation and structure lever, employees are provided incentives for providing quality improvement ideas showing the consistent improvement in the quality output across the groups and strategically-oriented group shows improvement in innovativeness. It is observed that plants are providing thrust on continuous improvement on current production system which results in reduction of production cost, ability to respond to changes in delivery speed (DV2). The IPPMC employs automated processes and machinery for conversion of raw material into final product and care is taken for designing the product that can be manufactured and assembled with ease (Levis, 2011). This improves delivery speed and reliability of delivery time (DV1). In addition to this, IPPMC are keen on developing environmental friendly products/packages (Khanna, 2011; Sheth, 2010) and strategically-oriented group is found to be better in this area. It seems that plants are not emphasising on and sharing real time production schedule information with suppliers because of fear of sharing critical information to the competitor, but some plants are developing long-term contracts with the suppliers (Geetha, 2010). There is difference in factory location and relocation of manufacturing plant (Kedia, 2011) which has effect on delivery speed. The decision making in factory reconditioning improves high-performance (PF2) and product durability (QT2). The size of plant in terms of employee and sales turnover is found consistent with manufacturing groups, i.e., larger the size of employee and sales turnover better the performance of the plant.

Authors have also pointed out that the difference in business performance. The sales growth is improved as a plant shows the higher level of manufacturing strategy implementation as compared to customer satisfaction.

\subsection{Analysis of a case company in less-implementer group}

Further, a case in the less-implementer group is selected as there are 68 plants in this category and needs to understand the reasons of inconsistencies in the manufacturing levers and resulting performance and these reasons can be applied to plants in other groups also. The average value of manufacturing strategy implementation (MSI_avg.) of case company is 1.92 (Table 5, shown in italic). The average value shows that is near the average value of less-implementer group. Even though the firm falls into less implementer group, the improvement in decision making in manufacturing levers is more than less-implementer group, which result in better outputs. For example, it is observed (refer to Table 5) the case plant regularly reviews the manufacturing strategy $(\mathrm{MCF} 2=3$ ) has resulted in improved level of decision making in using DFMA methods for production $(\mathrm{PT} 1=2)$. This has resulted in decrease in lead time to introduce new products (3) which is competitive priority of the industry (4.34). The lower emphasis on preventive maintenance practices $(\mathrm{PPC} 1=2)$ and factory reconditioning $(\mathrm{FC} 2=1)$ reflected in inability in reduction of production cost $(\mathrm{CT}=2)$.

The findings of deficiencies and strength relative to other group mean values (refer to Table 5) are discussed in this section. The manufacturing competence is not a substantial source of value added, and strategic initiatives, goals and objectives are communicated at less extent which hampers the improvement in manufacturing outputs (Thun, 2008). The production cost is reduced by taking decisions about raw material, systems and services 
soured from outside of the plant and checking that these decisions are consistent with manufacturing strategy. There is less improvement in the ability of production cost reduction as the plant functions are less integrated and strategic goals, objectives and strategies are communicated at lesser extent in the plant (Thun, 2008). The plant is found superior to less-implementer group, whereas inferior to other three groups especially in the amicable working of manufacturing function with other function. There is difference in providing high performance product (product capability, i.e., ability of feature to do things) because manufacturing competence is not considered substantial source of value added. This may be by not investing in competitive process technology in terms of machines and equipments to produce products. The above discussion shows that plant is not emphasising on manufacturing strategy implementation and reflected in less improvement in decision making in manufacturing levers and discussed below.

The improvement in manufacturing levers can be ascertained by improvement in manufacturing outputs. In the case company, there are no efforts in rewarding the employees for learning new skills (HR1) as well as the employees are promoted at much less extent based on effective deployment of skills in production system (HR2). This has reflected in hampering the motivation level of the employees to reduce setup time and accommodate change in delivery requirement/delivery speed (Samson and Terziovski, 1999) and reduction in time to introduce new products (Das and Narasimhan, 2001). The plant is placing less emphasis on sourcing decision as this group is reluctant to involve suppliers in product design (SR1) and reflected in lower level of delivery time reliability (DV1) (Narasimhan and Das, 2001). The less improvement in factory reconditioning reflected in hampering the ability of reducing the production cost (Avella et al., 2001). The implication of less emphasis on decision making in DFMA methods (PT1) result in reduction in lead time to introduce new products (IN1) and number of products introduced in the market in a year (IN2) (Swink et al., 2007). The marketing and finance function (FIM4) in case company is found that they know less about manufacturing function, as well as people do not operate as an integrated unit in production system (OSC1) which hampers the delivery speed of the product (Thun, 2008). The manufacturing capability of a case company is found less competitive and resulted in less improvement in manufacturing outputs and business performance. The above discussion put forth the areas for improvement for the case company. Though the discussion was limited to only few variables, other differences can be followed as shown in Table 5.

\subsection{Performance benchmarking for the case company in less-implementer group}

This is carried out in two steps. First step is finding the competitive priorities of the industry and second step shows the performance benchmarking for the case company.

Step 1 Calculating competitive priorities of IPPMC.

Competitive priorities are the manufacturing objectives, which represent the degree of relative emphasis given to activities in manufacturing function (Dangayach and Deshmukh, 2001). Competitive priorities denote strategic intent on developing certain manufacturing capabilities that may improve competitive position of the plant in marketplace. Several authors have stressed the importance of cost, quality, delivery and flexibility (Gerwin 1993; Boyer and Lewis, 2002). 
Respondents were asked to indicate importance in the manufacturing output and measured on five point Likert scale $(1=$ least important, $5=$ most important $)$. The study includes six competitive priorities identified by researchers (Miltenburg, 2008, Swink et al., 2007) into 11 dimensions. It is observed that top most competitive priority for IPPMC is ability of features to do things (4.59), followed by ability to produce range of products (4.38), decrease in lead time to introduce new products (4.34), and delivery speed (4.24), ability to respond to changes in delivery requirement (4.18), ability to incorporate features in product (4.08), product durability (4.08), new products introduced each year (3.97), reliability of delivery times (on time) (3.87), provide high-performance products (3.84), reduction in production cost (3.66).

Step 2 Performance benchmarking.

As pointed out earlier, performance benchmarking is carried out by finding the absolute difference in 11 pairs of competitive priorities and manufacturing performance of the plant. This is measures by summation of all absolute difference in terms of an inconsistency variable (Demeter, 2003). For example, let us take a case of a lessimplementer group as discussed in previous section. The competitive priorities are shown in previous section in order. Following this order, the manufacturing performance of the case is $3,2,3,2,3,2,2,2,2,3,2$ respectively. The inconsistency variable will be $|4.59-3|+|4.38-2|+|4.34-3|+|4.24-2|+|4.18-3|+|4.08-2|+|4.08-2|$ $+|3.97-2|+|3.87-2|+|3.84-3|+|3.66-2|=19.23$. This value is very large, showing large difference in manufacturing priorities of the industry and manufacturing performance of the case company. Conversely, the smaller value of inconsistency variable would indicate higher level of performance of the plant. This information can be utilised to understand the position of the competitive position of the plant in the industry.

\section{Conclusions}

In this research a comprehensive framework has been developed to demonstrate the implications of general manufacturing strategy implementation on manufacturing levers, manufacturing outputs and business performance. This is carried out by differentiating plants in terms of general manufacturing strategy implementation and classifying them into four groups as less-implementer, strategically-oriented, high-implementer and strategically-focused using cluster analysis technique. The strategically-focused group posses the highest level of manufacturing capability better than other three groups and it is in line with what Thun (2008) concluded that plants possessing higher level of manufacturing strategy implementation possess higher level of manufacturing outputs. The plants differ in more in decision making in human resource, process technology and facilities. Process technology and facilities are found to be the key enabler to develop competitiveness of the plants. A performance benchmarking is carried out using an inconsistency between manufacturing priorities and manufacturing performance. The inconsistency variable found could be utilised for benchmarking the manufacturing plants in IPPMC and source for continuous improvement in the manufacturing levers which lead to better performance. 


\section{Managerial implications, limitations and future scope}

This research has addressed strategic decisions in the packaging product manufacturing industry, which provides a new approach towards developing manufacturing configuration. The improvement in manufacturing levers will improve the capability to produce different outputs at higher level. The framework provides an approach for improvements/adjustments in the manufacturing capability by high or low emphasis on decision making in manufacturing.

This study tried to assess manufacturing strategy aspects in IPPMC. To analyse the manufacturing strategy orientation, only IPPMC has been selected. The results in this section of industry may not be true for other sections of the manufacturing industry. Since the inferences drawn based on this research comply with previous studies, this framework can be applied to other industries also. This could be explored in future studies. A mono-respondent approach is employed in administration of questionnaire. More sample size and more respondents at various levels in the company could be considered for future study to get more insight into manufacturing levers and priorities. This approach brings in bias with the same issue. Multi-respondent approaches incur high cost, but reduce the bias in response. This limitation could be considered in the future research. Due to limitation of approach employed for analysis, few decision making aspects are included in the study. The inclusion of more aspects in strategic orientation, manufacturing levers may be considered in the future research.

\section{References}

Avella, L., Fernandez, E. and Vazquez, C.J. (2001) 'Analysis of manufacturing strategy as an explanatory factor of competitiveness in the large Spanish industrial firm', International Journal Production Economics, Vol. 72, No. 2, pp.139-157.

Bayazit, O. and Karpak, B. (2007) 'An analytical network process-based framework for successful total quality management (TQM): an assessment of Turkish manufacturing industry readiness', International Journal of Production Economics, Vol. 105, No. 1, pp.79-96.

Bhutta, K.S. and Huq, F. (1999) 'Benchmarking - best practices: an integrated approach', Benchmarking: An International Journal, Vol. 6, No. 3, pp.254-268.

Boyer, K.K. and Lewis, M.W. (2002) 'Competitive priorities: investigating the need for trade-offs in operations strategy', Production and Operations Management, Vol. 11, No. 1, pp.9-20.

Camp, R.C. (1995) Business Process Benchmarking, ASQC Quality Press, Milwaukee, WI.

Chang, S., Yang, C., Cheng, H. and Sheu, C. (2003) 'Manufacturing flexibility and business strategy: an empirical study of small and medium sized firms', International Journal of Production Economics, Vol. 83, No. 1, pp.13-26.

Choudhari, S.C., Adil, G.K. and Ananthakumer, U. (2012) 'Exploratory case studies on manufacturing decision areas in the job production system', International Journal of Operations \& Production Management, Vol. 32, No. 11, pp.1337-1361.

Chung, W. and Swink, M. (2009) 'Patterns of advanced manufacturing technology utilization and manufacturing capabilities', Production and Operations Management, Vol. 18, No. 5, pp.533-545.

Cleveland, G., Schroeder, R.G. and Anderson, J.C. (1989) 'A theory of production competence', Decision Sciences, Vol. 20, No. 4, pp.655-668.

Coates, T.T. and McDermott, C.M. (2002) 'An exploratory analysis of new competencies: a resource based view perspective', Journal of Operations Management, Vol. 20, No. 5, pp.435-450. 
Dangayach, G.S. and Deshmukh, S.G. (2001) 'Manufacturing strategy: experience from select Indian organizations', Journal of Manufacturing Systems, Vol. 19, No. 2, pp.134-148.

Dangayach, G.S. and Deshmukh, S.G. (2004) 'Linkages between manufacturing strategy, business strategy and business excellence: a longitudinal study', International Journal of Industrial Engineering, Vol. 11, No. 3, pp.297-306.

Dangayach, G.S. and Deshmukh, S.G. (2006) 'An exploratory study of manufacturing strategy practices of machinery manufacturing companies in India', Omega, Vol. 34, No. 3, pp.254-273.

Dangayach, G.S. and Deshmukh, S.G. (2008) 'Implementation of manufacturing strategy: a multisector study of the Indian manufacturing industry', International Journal of Services and Operations Management, Vol. 4, No. 1, pp.1-33.

Das, A. and Narasimhan, R. (2001) 'Process-technology fit and its implications for manufacturing performance', Journal of Operations Management, Vol. 19, No. 5, pp.521-540.

De Mayer, A. (1998) 'Manufacturing operations in Europe: where do we go next', European Management Journal, Vol. 16, No. 3, pp.262-271.

Demeter, K. (2003) 'Manufacturing strategy and competitiveness', International Journal of Production Economics, Vols. 81-82, No. 1, pp.205-213.

Directory of Packaging Machinery Manufacturers of India (DPMMI) (2009) Indian Institute of Packaging (IIP), India.

Directory of Paper and Paper Boards of India (DPPBI) (2005) Indian Institute of Packaging (IIP), India.

Flynn, B.B., Schroeder, R.G. and Flynn, E.J. (1999) 'World class manufacturing: an investigation of Hayes and Wheelwrights foundation', Journal of Operations Management, Vol. 17, pp.249-269.

Fujimoto, T. (2004) 'A twenty-first-century strategy for Japanese manufacturing', Japan Echo, Vol. 31, No. 1, pp.20-25.

Gagan, D. (2010) 'India would certainly become a major packaging hub for packaging production', Modern Packaging and Design, January-February, pp.22-24.

Geetha, J. (2010) 'Leading path in flexible packaging', Modern Packaging and Design, JanuaryFebruary, pp.28-29.

Gerwin, D. (1993) 'Manufacturing flexibility: a strategic perspective', Management Science, Vol. 39, No. 4, pp.395-410.

Hair, J.F., Black, W.C., Babin, B.J. and Anderson, R.E. (2010) Multivariate Data Analysis, Prentice Hall, Upper Saddle River, New Jersey.

Han, C., Porterfield, T. and Li, X. (2012) 'Impact of industry competition on contract manufacturing: an empirical study of U.S. manufacturers', International Journal of Production Economics, Vol. 138, No. 1, pp.159-169.

Hayes, R.H. and Wheelwright, S.C. (1984) Restoring our Competitive Edge: Competing through Manufacturing, Wiley, New York.

Hill, T.J. (1989) Manufacturing Strategy: Text and Cases, Irwin, Homewood, IL.

Hong, P., Hong, S.W., Roh, J.J. and Park, K. (2012) 'Evolving benchmarking practices: a review for research perspectives', Benchmarking: An International Journal, Vol. 19, Nos. 4/5, pp.444-462.

Hutcheson, G. and Sofroniou, N. (1999) The Multivariate Social Scientist: Introductory Statistics Using Generalized Linear Models, Sage Publications, Thousand Oaks, CA.

Indian Yellowpages Directory (IYD) of packaging product manufacturers (2009) [online] http://www.products.indianyellowpages.com/packaging-paper/packaging-materials/ (accessed on August 10).

Institute of Packaging Machinery Manufacturers of India (IPMMI) (2009) Report on Packaging Machinery Manufacturers in India, Mumbai, India. 
Iyer, A., Koudal, P., Saranga, H. and Seshadri, S. (2011) Indian Manufacturing-Strategic and Operational Decisions and Business Performance, Indian Institute Of Management Bangalore, Working Paper no: 338.

Joshi, M. (2010) 'The future of growth as primary packaging: issues and challenges', Modern Packaging and Design, March-April, pp.12-15.

Karim, M.A., Smith, A.J.R., Halgamuge, S.K. and Islam, M.M. (2008) 'A comparative study of manufacturing practices and performance variables', International Journal Production Economics, Vol. 112, No. 2, pp.841-859.

Kedia, V. (2011) 'Indian rigid packaging segment is realizing importance of automation', Modern Packaging and Design, March-April, pp.22-23.

Khanna, J. (2011) 'Decoding progressive solutions', Modern Packaging and Design, March-April, pp.26-29.

Kim, J.S. and Arnold, P. (1996) 'Operationalizing manufacturing strategy - an exploratory study of constructs and linkages', International Journal of Operations and Production Management, Vol. 16, No. 12, pp.45-73.

Levis, B. (2011) 'Challenges before Indian packaging manufacturers', Modern Packaging and Design, March-April, pp.25-27.

Miller, J.G. and Roth, A.V. (1994) 'Taxonomy of manufacturing strategies', Management Science, Vol. 40, No. 3, pp.285-304.

Miltenburg, J. (1995) Manufacturing Strategy: How to Formulate and Implement Winning Plan, Productivity Press, Oregon.

Miltenburg, J. (2008) 'Setting manufacturing strategy for a factory-within-factory', International Journal Production Economics, Vol. 113, No. 2, pp.307-323.

Monga, A. (2010) 'Focus on integration and perfection', Modern Packaging and Design, November-December, pp.30-32.

Narasimhan, R. and Das, A. (2001) 'The impact of purchasing integration and practices on manufacturing performance', Journal of Operations Management, Vol. 19, No. 5, pp.593-609.

Narasimhan, R. and Jayaram, J. (1998) 'Causal linkages in supply chain management: an exploratory study of North American manufacturing firms', Decision Sciences, Vol. 29, No. 3 , pp.579-605.

Nunally, J.C. (1978) Psychometric Methods, McGraw-Hill, New York.

Patil, P.P., Narkhede, B.E. and Akarte, M.M. (2012a) 'An exploratory study of manufacturing strategy of packaging product manufacturing companies in India', International Journal of Quality Research, Vol. 6, No. 3, pp.233-249.

Patil, P.P., Narkhede, B.E. and Akarte, M.M. (2012b) 'Impact of process technology on manufacturing outputs in an Indian packaging product manufacturing company: a case study', Performance Improvement, Vol. 51, No. 7, pp.14-20.

Porter, M.E. (1980) Competitive Strategy: Techniques for Analyzing Industries and Competitors, Free Press, New York.

Porter, M.E. (1985) Competitive Advantage: Creating and Sustaining Superior Performance, Free Press, New York.

Prahalad, G.K. and Hamel, G. (1990) 'The core competence of organization', Harvard Business Review, May-June, pp.1-15.

Ravi, K. (2010) 'Maintaining quality standard is critical to market growth', Modern Packaging and Design, January-February, pp.24-25.

Rho, B., Park, K. and Yu, Y. (2001) 'An international comparison of the effect of manufacturing strategy-implementation gap on business performance', International Journal of Production Economics, Vol. 70, No. 1, pp.89-97. 
Rosenzweig, E.D. and Easton, G.S. (2010) 'Trade offs in manufacturing? A meta-analysis and critique of the literature', Production and Operations Management, Vol. 19, No. 2, pp.127-141.

Rosenzweig, E.D. and Roth, A.V. (2004) 'Towards a theory of competitive progression: evidence from high-tech manufacturing', Production and Operations Management, Vol. 13, No. 4, pp.354-368.

Rosenzweig, E.D., Roth, A.V., Dean, J.W. Jr. (2003) 'The influence of an integration strategy on competitive capabilities and business performance: an exploratory study of consumer product manufacturer', Journal of Operations Management, Vol. 21, No. 4, pp.437-456.

Samson, D. and Terziovski, M. (1999) 'The relationship between total quality management practices and operational performance', Journal of Operations Management, Vol. 17, No. 4, pp.393-409.

Schroeder, R.G. and Flynn, B.B. (2001) High Performance Manufacturing: Global Perspectives, John Wiley \& Sons, New York.

Sheth, S. (2010) 'Innovative branding solution: finding right fit', Modern Packaging and Design, March-April, pp.46-47.

Singh, R.K., Garg, S.K. and Deshmukh, S.G. (2007) 'Strategy development for competitiveness: a study on Indian auto component sector', International Journal of Productivity and Performance Management, Vol. 56, No. 4, pp.285-304.

Skinner, W. (1969) 'Manufacturing-missing link in corporate strategy', Harvard Business Review, Vol. 47, No. 3, pp.136-145.

Skinner, W. (1974) 'The focused factory', Harvard Business Review, Vol. 52, pp.113-121.

Swink, M., Narasimhan, R. and Kim, S.W. (2005) 'Manufacturing practices and strategy integration: effects on cost efficiency, flexibility, and market-based performance', Decision Sciences, Vol. 36, No. 3, pp.427-457.

Swink, M., Narasimhan, R. and Wang, C. (2007) 'Managing beyond the factory walls: effects of four types of strategic integration on manufacturing plant performance', Journal of Operations Management, Vol. 25, No. 1, pp.148-164.

Thun, J. (2008) 'Empirical analysis of manufacturing strategy implementation', International Journal Production Economics, Vol. 113, No. 1, pp.370-382.

Vickery, S.K., Droge, C. and Markland, R.E. (1993) 'Production competence and business strategy: do they affect business performance?', Decision Sciences, Vol. 24, No. 2, pp.435-456.

World Packaging Organization (WPO) (2008) Market Statistics and Future Trends in Global Packaging, Brazil. 